\title{
Meaning of well-being of older institutionalized persons in abandonment situation
}

\author{
Significado de bienestar del anciano institucionalizado en situación de abandono \\ Significado de bem-estar do idoso institucionalizado em situação de abandono
}

\section{Wendy Sindy Nallely Flores Martínez' ORCID: 0000-0001-8347-9640}

María de Jesús Jiménez González' ORCID: 0000-0003-3806-0714

Norma Elvira Moreno Pérez' ORCID: 0000-0003-1829-3916

Raúl Fernando Guerrero-Castañeda' ORCID: 0000-0003-3996-5208

'Universidad de Guanajuato, División de Ciencias de Salud e Ingenierías. Celaya, Guanajuato, Mexico.

How to cite this article: Flores WSN, Jiménez-González MJ, Moreno-Pérez NE, Guerrero-Castañeda RF. Meaning of well-being of older institutionalized persons in abandonment situation.

Rev Bras Enferm. 2020;73(Suppl 3):e20200123. doi: http://dx.doi.org/10.1590/0034-7167-2020-0123

\section{Corresponding author:}

Raúl Fernando Guerrero-Castañeda E-mail: ferxtom@hotmail.com

EDITOR IN CHIEF: Antonio José de Almeida Filho ASSOCIATE EDITOR: Priscilla Broca

Submission: 04-24-2020

Approval: 08-09-2020

\begin{abstract}
Objective: To understand the meaning of well-being of older persons in situation of abandonment. Methods: a qualitative phenomenological study, carried out in a nursing home in Tepic, Nayarit, from 2017 to 2019. Intentional sampling with 12 older persons aged 60 and above. Data collection occurred by phenomenological interview. The ethical criteria of the General Health Law were respected. Participants signed the Informed Consent Form. Data analysis took place through phenomenological analysis. Results: four themes have emerged: 1. Living Activities of Daily Living; 2. Attention to physical needs; 3 . Coexistence: 4. Spirituality experience. Conclusion: for older persons, living institutionalized implies a process of adaptation and transformation to their context and state of life, restructuring their needs that provide well-being. It is important to approach these scenarios to establish ways of experiencing aging that favor a full quality of life.

Descriptors: Aged; Institutionalization; Qualitative Research; Nursing; Homes for the Aged.
\end{abstract}

\section{RESUMEN}

Objetivo: Comprender el significado de bienestar del anciano en una situación de abandono. Métodos: Estudio cualitativo fenomenológico, realizado en asilo de Tepic, Nayarit, de 2017 a 2019. Muestreo intencional con 12 adultos mayores, con 60 años en adelante, hombres y mujeres. Recolección de datos por entrevista fenomenológica. Se respetaron criterios éticos de la Ley General de Salud, participantes firmaron consentimiento informado. Análisis de datos a través de análisis fenomenológico. Resultados: Emergieron cuatro temas: 1. Vivir lo cotidiano de las actividades de la vida diaria; 2 . La atención en las necesidades físicas; 3. La convivencia y 4. Vivencia de la Espiritualidad. Conclusión: Para el anciano vivir institucionalizado implica un proceso de adaptación y transformación a su contexto y estado de vida, reestructura sus necesidades que lo proveen de bienestar, es importante el acercamiento a estos escenarios para establecer formas de vivencia del envejecimiento que favorezcan la calidad de vida plena.

Descriptores: Anciano; Institucionalización; Investigación Cualitativa; Enfermería; Hogares para Ancianos.

\section{RESUMO}

Objetivo: Compreender o significado de bem-estar do idoso em situação de abandono. Métodos: estudo qualitativo fenomenológico, realizado em uma casa de repouso em Tepic, Nayarit, de 2017 a 2019. Amostragem intencional ocorreu com 12 idosos com 60 anos ou mais, homens e mulheres. Coleta de dados por entrevista fenomenológica. Os critérios éticos da Lei Geral de Saúde foram respeitados. Os participantes assinaram o Termo de Consentimento Livre e Esclarecido. Análise de dados ocorreu por meio de análise fenomenológica. Resultados: emergiram quatro temas: 1 . Vivenciando as atividades diárias da vida diária; 2. Atenção às necessidades físicas; 3 . Coexistência; 4. Experiência de Espiritualidade. Conclusão: para o idoso, viver institucionalizado implica um processo de adaptação e transformação ao seu contexto e estado de vida, reestruturando suas necessidades que proporcionem bem-estar, sendo importante a abordagem desses cenários para estabelecer formas de vivenciar o envelhecimento que favoreçam uma qualidade de vida plena.

Descritores: Idoso; Institucionalização; Pesquisa Qualitativa; Enfermagem; Instituição de Longa Permanência para Idosos. 


\section{INTRODUCTION}

Population aging is the result of declining fertility accompanied by economic growth, better nutrition, healthier lifestyles, better control of infectious diseases, as well as advances in science, technology and medicine ${ }^{(1)}$.

Aging involves physical, social, and psycho-emotional changes in care. In some cases, the health of older persons may have deteriorated; they have lost some of their old friends and family, often their spouse. It is likely that they no longer have the same income, their lives are modified in many ways and those changes result in stress; however, in general, older adults suffer less mental disorders, are happier and feel more satisfied with life than younger adults, subjective well-being increases in general during the course of life and even more in old age. This reflects the value of a mature attitude and contributes to successful aging ${ }^{(2-3)}$.

Reaching old age can be synonymous with various situations, some of them unpleasant such as loneliness, abuse, discrimination or abandonment ${ }^{(4)}$. These conditions have increased notably in different countries worldwide, including Mexico. When one speaks particularly of elder abandonment, this can be defined as lack of attention and care on the part of their family and a large part of society in general ${ }^{(5)}$.

This stage of human life becomes very difficult for many older persons, since they face situations of abandonment when their children leave home to form new families, and visits become sporadic or null. They lose their functions, abilities, loved ones (widowhood situation), jobs, and their own family that abandon them ${ }^{(6)}$. This leads to staying home alone and living in solitude, turning life into a difficult and complicated stage.

The number of older adults living in retirement homes is increasing and not only can they be seen in abandonment in these houses, but this phenomenon can also be observed at the hospital and community level ${ }^{(7)}$. Abandonment is neglect by family members concerning some of their family members. Elder abandonment is a dynamic that is experienced daily. There are countless stories that exist about abandonment, displacement or exile of the family nucleus ${ }^{(8-9)}$. Generally, institutionalization occurs when children or primary caregivers abandon an older person. Institutionalization occurs usually due to chronic diseases, widowhood, or cognitive impairment ${ }^{(10)}$.

Institutionalization is sometimes a family decision due to the care that an older person may need ${ }^{(11)}$. Sometimes, widowhood and institutionalization increase the feeling of loneliness that can lead to other consequences on the physical and emotional health of older persons ${ }^{(12)}$. Generally, institutionalization can affect self-acceptance, social support and personal growth ${ }^{(13)}$. Even with these losses, it was found that older institutionalized persons actively face life ${ }^{(14)}$ and, therefore, could build their well-being.

Well-being is a concept that has its meaning in the perception or subjectivity of human beings and is understood as a set of factors that a person needs to enjoy a good quality of life. These factors lead the subject to enjoy a quiet existence and in a state of satisfaction. Well-being, therefore, includes those things that positively affect the quality of life: decent employment, economic resources to satisfy needs, housing, access to education and health, time for leisure, among others ${ }^{(15-16)}$.
Subjective well-being corresponds to an area of quality of life and contributes the psychosocial component focusing on the perception of the vital conditions of human beings ${ }^{(17)}$. Subjective well-being together with objective living conditions and personal values shape the overall quality of life of a person ${ }^{(18)}$. Constructing well-being has psycho-emotional connotations in relation to a person's state of life, subjectively constituted. It is necessary to approach it from qualitative approaches, being phenomenology an ideal method to unveil the meaning of the lived experiences that constitute this perception of well-being.

The need for older persons' approach to subjective well-being stands out for its importance in the ways of recreating senses of a reality lived specifically, especially when this reality is lived in a retirement home. An investigation concluded that social support and perceived health are directly related to psychological wellbeing, for which it is proposed that social support is a constant in older persons. Moreover, men report greater psychological well-being and better perception of health than women. People who are married or have a stable partner reported greater psychological well-being and greater perceived social support than those without a stable partner ${ }^{(19)}$. Although, for example, a non-alarming level of loneliness has been detected, older persons with family support express a lower risk of feeling lonely ${ }^{(20)}$.

In Spain, results confirm the importance of personal ties. It is noteworthy that active life, reminiscences and happy memories, optimism, satisfaction with life and perceived autonomy are closely linked to the well-being of older persons ${ }^{(21)}$, resources that can be lost during institutionalization.

For this reason and considering that the dynamics of institutionalization influences activities of daily living, satisfaction with life and psychological well-being and understanding wellbeing in these environments can guide nursing professionals to develop care protocols for older persons, including aspects related to normal changes in the aging process; strategies aimed at the grieving process for the loss of functions, until reaching incorporation of older persons in groups and family activities.

Subjective well-being is a characteristic endowed with perception that constitutes meanings, so it is essential to reveal this subjectivity in the context of institutionalization based on the experience of elderly actors. Subjective well-being resulting from this psychosocial construct comprises the cognitive and affective component ${ }^{(22) \text {; }}$ therefore, its understanding resides in the awareness of satisfactory experiences that shape the daily life of older persons, their ways of life, their relationships and perception of the world.

It can be said that human beings build their perception of well-being in satisfying experiences, which are reserved in consciousness and which are significant, which allows them to be integrated to build their own meaning from intersubjective relationships ${ }^{(23)}$. It is precisely phenomenology that points to this form of knowledge built from the essential description of these life experiences that allow us to build everyday meanings.

Therefore, the methodological framework of descriptive phenomenology was chosen, considering Husserl's concepts in relation to reflexivity around phenomena ${ }^{(23)}$ and the experiences that constitute human beings as well as their meanings. To understand the meaning of subjective well-being, it is necessary to unveil this phenomenon as it appears in the consciousness of older 
persons. Thus, phenomenology in this perspective tries to reach the essence of the experiences that constituted the subjective well-being of older persons, allowing to unveil the meaning of a phenomenon by understanding it in people's life experiences; in this case, older persons who experience abandonment and how much well-being means from their lived reality.

\section{OBJECTIVE}

To understand the meaning of well-being of older persons in situation of abandonment.

\section{METHODS}

\section{Ethical aspects}

The ethical criteria of the General Health Law on Research for Health in Mexico have been respected ${ }^{(24)}$. Participant's anonymity was respected by granting a participation code of I1 ... I12. Informed written consent was provided to participants. The project was approved by the Bioethics Committee of the Division of Health Sciences and Engineering of the Celaya-Salvatierra Campus of Universidad de Guanajuato, under code CBDCSI-71140924.

\section{Type of study}

This is a qualitative study with a descriptive phenomenological approach, since it seeks the essence of the lived reality that determines the significant patterns of people. Consolidation Criteria for Reporting Qualitative Research (COREQ) have been followed ${ }^{(25)}$.

\section{Study setting}

This investigation was carried out in a retirement home in Tepic City, Nayarit, Mexico, aimed primarily at housing older adults aged 60 and above. The study started in mid-2017 and ended in mid-2019 with the writing of this article, time considered from its analysis and approval by the committee and institution where it was carried out until the writing of this document.

\section{Data source}

An intentional sampling was considered ${ }^{(26-27)}$. Participants were adults aged 60 years and above, male and female who wished to participate in the study, retirement home residents and who did not receive any visits from their relatives. Older persons who were not in full use of their mental faculties or in communication with the family were not part of the investigation. A total of 12 older persons participated, and the criterion of information saturation was considered based on the possession of information to explain the phenomenon ${ }^{(27)}$.

\section{Collection and organization of data}

For data collection, the phenomenological interview was used, which is defined as a resource to search for the meanings attributed by them to their experience in a given situation ${ }^{(28)}$. Data collection was carried out in 2017. To that end, an interview guide was used as an instrument, the first part composed of identification data and the second with triggering phenomenological questions: what does well-being mean for you? What is being well right now for you? All interviews were audio-recorded to preserve the information, after the interview, each of them was faithfully transcribed in a word processor, thus it was also possible to determine information saturation. The criteria of scientific rigor were followed for qualitative research credibility, transferability, confirmability and theoretical-epistemological adequacy ${ }^{(29)}$. The interviews were conducted by the main researcher and two collaborating investigators, with an average duration of 57.7 minutes. The minimum was 45 minutes and the maximum was 68 minutes.

\section{Data analysis}

Once the researchers had transcribed the interviews carried out, the data were analyzed based on Martínez Miguélez's phenomenological structural stage $\mathrm{e}^{(30)}$, which indicates the capture of meaning in reality and is formed by six Steps. First, general reading of the description of each protocol; second, delimitation of natural thematic units; third, determination of the subject that dominates each thematic unit; fourth, expression of the central theme in scientific language; fifth, integration of all central themes in a particular descriptive structure; sixth, integration of all particular structures in a general structure.

\section{RESULTS}

Table 1 presents participants' characterization:

Table 1 - Participants' characterization, Tepic, Mexico, 2019

\begin{tabular}{cccccc}
\hline $\begin{array}{c}\text { Interviwee } \\
\text { Code }\end{array}$ & Age & Sex & Education & Occupation & $\begin{array}{c}\text { Marital } \\
\text { Status }\end{array}$ \\
\hline 11 & 78 & Female Elementary & Housewife & Married \\
12 & 81 & Male & Elementary & Merchant & Married \\
13 & 82 & Female Elementary & Housewife & Widow \\
14 & 74 & Female & Elementary & Farmer & Single \\
15 & 73 & Male & Elementary & Plumber & Separated \\
16 & 73 & Male & None & Merchant & Separated \\
17 & 74 & Female & Elementary & Seamstress & Widow \\
18 & 89 & Female & None & Housewife & Widow \\
19 & 76 & Male & Elementary & Farmer & Widower \\
110 & 78 & Male & Elementary & Laborer & Single \\
111 & 76 & Female Elementary & Housewife & Married \\
112 & 72 & Female Elementary & Housewife & Widow \\
\hline
\end{tabular}

From analysis of information, different thematic units have emerged, which are identified in four central themes, which in turn allow integrating the theme "Meaning of well-being in older institutionalized persons in situation of abandonment". The central themes were integrated as follows:

\section{Living Activities of Daily Living}

This topic highlights that abandonment has a meaning for carrying out daily activities. One way to face the situation of being unaccompanied comes to highlight the need to be busy and to be able to continue the daily life. The following speeches highlight the aforementioned: 
Well, I take out the grass, the herbs, then you shake here; I wash a little and go to the laundry. (14)

Look, I fix something or other here, I feel comfortable, like when I used to work. (15)

On Thursdays they take us to dance Danzón [a typical dance] in the square, dancing is Good. (19)

Well, I was not a person who went to dances [parties], I love the lottery, I love games like that. (14)

\section{Attention to physical needs}

The issue of physical needs is a way of experiencing abandonment. These needs are met by someone else, a way of looking after the other in a retirement home; basic needs such as food and hygiene are met; needs reflect being cared for. This is stated by the following participants.

They give us food, shelter, we are comfortable with that. (16)

They bathe us early, later would be better, but there are many of us and angry people, but they help us out. (I5)

Well, they give me food, beans, whatever, but it's never missing. (14)

\section{Coexistence}

Coexistence with other older adults, whether in the form of friendship or relationship, is what supports abandonment of other people in retirement homes, a form of bond is created that gives strength to older persons. Being in contact with other older persons in similar situations is what reflects a form of relationship and well-being. This is how the following participants express it:

I already feel calm, stress goes away, and who talks to you right here then. (I2)

If we look for a way to have fun on this planet, in this retirement home, we try to understand each other. (16)

We live in comfort thanks to the friendships we made here. (16)

We have been having a very comfortable time since we got married. (I1)

\section{Spirituality experience}

Spirituality is a resource for well-being. Older persons reflect in their speeches the need to believe in something divine, claim to believe in God, emphasize that there are some who express that they believe in God, but do not attend the activities, such as participant I1. The other participants report believing and participating in religious activities related to the experience of spirituality. This is how the following speeches show:

I am with God in heaven haha ... nothing happens to me here, blessed be God that we have everything. (I5)
I feel good at Mass, and the father comes on Sundays. (19)

I am a Catholic, I believe in God and in the saints and all, but I never go to mass, God forgive me, but I never Will. (I1)

Walk as God gives us permission; it's a maximum good. (18)

If I go to mass after I start, I like to go, I feel beautiful. (I4)

\section{DISCUSSION}

Constructing the phenomenon of the meaning of well-being in older institutionalized persons in situation of abandonment constitutes precisely the ways of life and coping with this situation of abandonment, reconstructing daily the satisfaction in carrying out daily activities that provide them with a sense of functionality; this may be related to the feeling of being independent, giving older persons awareness of being able to perform activities.

Intersubjective reduction contemplates building intentional experiences, thus constituting a phenomenon that, based on the experiences and acts, as well as the perception of daily satisfaction, will be constructed as intentional experience ${ }^{(23)}$.

Building subjective well-being is, therefore, grounded in the intentionality of older persons who reconstruct their world. Husserl ${ }^{(23)}$ calls it the lifeworld of human beings, the subjective internal life and its manifestation in the feeling of well-being.

The origin of the term activities of daily living (ADL) arises mainly in the field of health. ADL are defined as a set of behaviors that a person performs on a daily basis, to live autonomously and integrated with his or her environment and fulfill his or her social role ${ }^{(21)}$. Carrying out these activities considered at their basic and instrumental levels can support older persons to have a feeling of independence, which is associated with an idea of health and well-being. Subjective well-being is reflected in the way of expressing the quality of personal life, so that the less dependence and greater self-care, the better perceived health, well-being and a better quality of life is expressed ${ }^{(31-32)}$.

Therefore, maintaining performance of ADL favors well-being perception, another author points out that even when there is a deficiency in the state of health, different strategies are adopted to maintain the greatest possible independence ${ }^{(33)}$. Therefore, it is imperative to maintain and give value to performance of ADL that give a sense of well-being that, although subjective, is what favors manifesting having a good quality of life.

This is related to the perception of functional well-being, which must be motivated in any context, in order to promote the feeling of well-being ${ }^{(34)}$. Functionality is then built into everyday forms, so well-being involves the satisfaction of physical needs, basically determined by food and higiene needs.

Maslow established a hierarchy according to its importance. At the base of the pyramid are physiological needs; when they are not met, the human organism suffers significant damage or ceases to exist, mainly due to hunger, thirst, sleep, lack of clothing and shelter ${ }^{(35)}$.

Although it is true to say that well-being is health and health is to be able to do ${ }^{(22)}$, it is important to emphasize that basic needs, even when provided by others, are important for older persons, attributing a subjective value to their personal well-being. 
Basic needs are needs related to health, and satisfaction of those needs estimates the perception of health in general ${ }^{(36)}$. These needs, as well as independence, correspond to the first step of the Maslow's pyramid, being, therefore, the first to be met. Moreover, older institutionalized persons, since they have experienced losses and especially family abandonment, seek accompaniment that evokes participation in the feelings or behaviors of others, in order to understand or act with them on the things that happen around them. Social support is a strong predictor of subjective wellbeing ${ }^{(33)}$. Some participants had the feeling of bonding with the couple. As they are older institutionalized persons, family relations are reduced, communication and relationships with other sectors are reduced. But some highlight the importance of a couple; some authors point out that health and well-being are composed of "being well with the family", highlighting family relationships with children ${ }^{(33)}$; however, in this case, it is important to feel integrated with a partner, which is also to be well.

Living with other older adults favors not only well-being but also fullness and a sense of understanding of life itself in old age ${ }^{(37)}$, being in a retirement home, older adults coexist with each other, make friends, create bonds and favor its integration. Older adults reported that they live together, talk and also try to understand. Abandonment is corrected by living together. Social support is important because it favors the creation of relationships and the functionality of older persons ${ }^{(38)}$. When family support is distant, there is a rapprochement with friends, ordinary people or cohabitants, also resulting in a form of bond that brings health and well-being ${ }^{(39)}$.

The social sphere is strengthened by living with other older persons; however, it is necessary the participation and intervention of health professionals, in order to favor other types of relationships, interaction of older persons outside an institution or approach of other generational groups to live with older persons can favor their social support ${ }^{(40-41)}$. In this regard, well-being is constructed as an intersubjective phenomenon where the other is contemplated in $\mathrm{me}^{(23)}$. The conjecture of coexistence with others constitutes the notion of well-being in everyday relationships, a way of experiencing the other in personal reality. Thus, well-being is intersubjective, essentially constituted in life and relationships.

A comprehensive approach to build well-being also encompasses the spiritual experience as a resource focused on the divine and the religious practice of older persons. They highlight the beliefs in a higher being, spirituality is recognized as what gives reality and essential meaning to the religious life of a believer is spirituality. Spirituality constitutes well-being in a characterization of a feeling of integration with life and the world; as a dynamic functional process, which develops in the singularity of the subject and is subsequently expressed in the social. Spirituality allows one to feel life, both in individual life and in community life, as a whole full of meaning ${ }^{(42)}$. Spirituality in institutionalization becomes a resource to face various situations associated with old age and the isolation process ${ }^{(43-44)}$, even when there is a clear difference between being religious or spiritual, in both an element is faith, this being a resource to overcome stressful events, deal with difficult processes and make sense of loneliness ${ }^{(45-46)}$.

Gerontotranscendence evokes an old age lived with wisdom thanks to the approach to spirituality. The spiritual dimension is a dimension increased in old age that gives older persons a sense about health and life itself, helping them to recognize various situations and to give a meaning to each of them ${ }^{(47)}$, so that spirituality also has an impact on the meaning of well-being ${ }^{(48-49)}$; even if there is nothing in other aspects, the resource that remedies everything is God, as a source of encouragement and support for older persons, especially when there is isolation.

Threfore, the meaning of well-being in older institutionalized persons in situation of abandonment is not limited to certain external situations, even in the feeling of abandonment; the perception of that well-being is constituted, which contributes to a continuous development of human life; although traditionally not recognized as a part of the life cycle in which there can be great gains, it can be lived as a psychologically positive experience.

Although the feeling of well-being has quantitative implications that can guide its measurement with certain aspects of life, it is recreated in the daily lives of older persons; when they are institutionalized, they try to adapt to new situations. They do not abandon themselves, on the contrary, they establish standards of daily life. Subjectivity is linked to the simplest forms of life, feeling functional even and with support, basic needs met and support in accompanying others and spirituality; the latter considers intentionality in daily experiences and the relationships between them that reconstruct the world of older persons ${ }^{(23)}$. Older persons constitute them as part of their own experience and thus their meaning is constituted.

Building a subjective well-being, far from being isolated, contributes to the development of older persons in their life history and in their daily forms, the understanding of the integration of the elements that constitute it, contributes to the psychoemotional and social aspects. Even though they are abandoned in retirement homes, the institutions provide older persons with a sense of belonging and allow them to face this situation of abandonment in an active and resilient way. The perception of vital aspirations, far from being a failure, is a vital reconstruction in the development of older institutionalized persons; and along with that, feelings, experiences and daily experiences become elements to build satisfaction with life and meaning of life and, therefore, manifestation of well-being.

Nursing professionals msut be involved with these daily environments. Through care they understand the life situations that make up the feeling of well-being, in addition to the other components that must be satisfied to integrate the quality of life of older persons in still complicated environments.

\section{Study limitations}

The study's limitations are that the data cannot be generalized; however, this also represents a strong point, since these results can be transferred to older persons in similar situations. Another limitation was the length of the data collection period, which took longer than planned, as the researchers who conducted the interviews took longer to get closer to the setting and empathize with the older persons under study.

\section{Contributions to nursing}

The benefits of taking a nursing course are generating a personcentered care in retirement homes, a holistic care that allows older 
persons to preserve their independence, favoring performance of their activities to the extent of their functional capacity.

Likewise, nursing is a course that should favor and promote care, which is why it emphasizes that it is necessary to meet basic needs coupled with independence and spiritual care ${ }^{(49)}$.

\section{FINAL CONSIDERATIONS}

For older institutionalized persons, living away from their family implies a process of transformation for their new context and lifestyle; older persons restructure their basic needs that provide them with well-being. The meaning of well-being in relation to elder abandonment reflects precisely that they are involved with the dynamics of human needs, highlighting coexistence, satisfaction of physical needs, perception of functionality, and spirituality.
Constructing well-being points to a subjective component, revealing that it is perceived in the daily lives of older persons, showing personal satisfaction even in the conditions of abandonment in an institution.

The meaning of well-being involves subjective knowledge that links the notion of feeling good about oneself, despite the limitations or disadvantages that one may have. It is advisable to adapt comprehensive health care for older persons to the context in which they live so that they can experience well-being at this stage of life.

Thus, health professionals should strengthen and promote, through care and education, all those actions aimed at strengthening autonomy and Independence activities in older persons.

\section{ACKNOWLEDGMENT}

We thank the study participants and the institution of residence.

\section{REFERENCES}

1. Sánchez BO, Martínez AJ, Florit SPC, Gispert AEA, Vila VM. [Population ageing: some considerations from the field of the Antrhopoly] Rev Med Electrón [Internet]. 2019 [cited 2020 Jul 01];41(3):708-24. Available from: http://scielo.sld.cu/pdf/rme/v41n3/1684-1824rme-41-03-708.pdf Spanish.

2. Meléndez JC, Agustí AI, Delhom I, Reyes MF, Satorres E. [Subjective and psychological well-being: young and older adults' comparison]. Summa Psicológica UST. 2018;15(1):18-24. doi: 10.18774/0719-448x.2018.15.335 Spanish.

3. Vento EM, Ulloa EH, Oliva YDR, Dorta YO. [Characterization of the perception of the family relations of elderly adults incorporated to the grandparents' clubs]. Medimay[Internet]. 2015 [cited 2019 Oct 10];21(2):346-56. Available from: http://revcmhabana.sld.cu/index.php/ rcmh/article/view/779/pdf_52 Spanish

4. Acosta CO, Tánori J, Farcía R, Echeverría SB, Vales JJ, Rubio L. [Loneliness, depression and quality of life in Mexican older adults]. Psicol Salud [Internet]. 2017 [cited 2019 Oct 10];27(2):179-88. Available from: http://psicologiaysalud.uv.mx/index.php/psicysalud/article/ view/2535/4417 Spanish

5. Toribio-Ferrer C, Franco-Barcenas S. [Perception of older adults about their experiences in a nursing home]. Rev Enferm Inst Mex Seguro Soc. [Internet]. 2018 [cited 2019 Oct 10];2018;26(1):16-22. Available from: http://revistaenfermeria.imss.gob.mx/editorial/index.php/revista_ enfermeria/article/view/293/709 Spanish

6. Araújo AA, Rebouças Barbosa RAS, Menezes MSS, Medeiros IIF, Araújo RF, Medeiros CACX. Quality of life, family support, and comorbidities in institutionalized elders with and without symptoms of depression. Psychiatr Q. 2016;87(2):281-91. doi: 10.1007/s11126-015-9386-y

7. Damián A. [Social security, pensions and old age adults' poverty in Mexico]. Acta Sociol. 2016;70:151-72. doi: 10.1016/j.acso.2017.01.007 Spanish

8. Villarreal JF, Cárdenas VH, Miranda JM. [Functional assessment of older adults related to family abandonment]. Enferm Investig [Internet]. 2017 [cited 2019 Oct 10];2(1):14-7. Available from: http://revistas.uta.edu.ec/erevista/index.php/enfi/article/view/462/786 Spanish

9. Rzeszut SM. The need for a stronger definition: recognizing abandonment as a form of elder abuse across the United States. Fam Court Rev. 2017 ;55(3):444-57. doi: 10.1111/fcre.12295

10. Mocellin D, Aires M, Fuhrmann AC, Pizzol FLFD, Paskulin LMG. Filial responsibility: what are the attitudes of adult child caregivers on the institutionalization of aged parents?. Rev Gaúcha Enferm. 2019;40:e20180377. doi: 10.1590/1983-1447.2019.20180377

11. Figueiredo MCCM, Ferreira FA, Nunes ESC, Araújo AM, Araújo PE, Souza GP, Damaso CR. [Institutionalized elderly: decision and consequences in family relations]. Rev Kairós Gerontol. 2018;21(2):241-52. doi: 10.23925/2176-901X.2018v21i2p241-252 Portuguese

12. Bermeja Al, Ausín B. Programs to combat loneliness in the institutionalised elderly: a review of the scientific literature. Rev Esp Geriatr Gerontol. 2018;53(3):155-64. doi: 10.1016/j.regg.2017.05.006

13. Salgado EM, Noa LM, Matos LD, Cardero LD, Castillo PY. [Influence of some biopsychosocial factors in the subjective well-being of institutionalized elderly]. MEDISAN [Internet]. 2016 [cited 2020 Jul 02];20(10):2195-201. Available from: http://scielo.sld.cu/scielo. php?script=sci_arttext\&pid=S1029-30192016001000001\&lng=es Spanish

14. Torres PWI, Flores GMM. [Predictive factors of subject well-being in older people Factores predictores del bienestar subjetivo en adultos mayores]. Rev Psicol. 2018;36(1):9-48. doi: 10.18800/psico.201801.001

15. Satici SA. Psychological vulnerability, resilience, and subjective well-being: the mediating role of hope. Person Indiv Diff. 2016;102:68-73. doi: 10.1016/j.paid.2016.06.057 
16. Carballeira M, González JA, Marrero RJ. Cross-cultural differences in subjective well-being: Mexico and Spain. An. psicol. 2014;31(1):199-206. doi: 10.6018/analesps.31.1.166931

17. Suriá MR. [Subjective well-being, resilience and disability]. Acciones Investig Soc. 2016;(36):113-40. doi: 10.26754/ojs_ais/ais.2016361490 Spanish

18. Bautista-Rodríguez LM. La calidad de vida como concepto. Rev Cien Cuidad. 2017;14(1):5-8. doi: 10.22463/17949831.803 Spanish

19. Vivaldi F, Barra E. [Psychological Well-Being, Perceived Social Support and Health Perception Among Older Adults]. Ter Psicol. 2012;30(2):239. doi: 10.4067/S0718-48082012000200002 Spanish

20. Azeredo ZA, Afonso MA. Loneliness from the perspective of the elderly. Rev Bras Geriatr Gerontol. 2016;19(2):313-24. doi: 10.1590/1809-98232016019.150085

21. Flecha AC. [Subjective psycological well-being of senior residents in nursing homes]. Soc Rev Interuniv[Internet]. 2015 [cited 2019 Oct 10];(25):319-41. Available from: https://recyt.fecyt.es/index.php/PSRI/article/view/38030/21483 Spanish

22. Riffo AG, Donoso AA. [Bibliometric análisis of subjective well-being]. INFAD. 2019;2(2):125-34. doi: 10.17060/ijodaep.2019.n2.v2.1748 Spanish

23. Husserl E. La idea de la fenomenología. México: Fondo de Cultura Económica; 2015.

24. Secretaria de Salud de México. Reglamento de la Ley General de Salud en materia de investigación para la salud. México; 2017.

25. Tong A, Sainsbury P, Craig J. Consolidated criteria for reporting qualitative research (COREQ): a 32-item checklist for interviews and focus groups. Int J Qual Heal Care. 2017;19(6):349-57. doi: 10.1093/intqhc/mzm042

26. Pérez-Luco R, Lagos L, Mardones R, Sáez F. Research designs and qualitative sampling: the complex of submitting the flexibility of the emerging method to an aprioristic taxonomy. Atas CIAIQ2017. [Internet]. 2018 [cited 2019 Oct 05];2:1111-20. Available from: https://www. proceedings.ciaiq.org/index.php/ciaiq2017/article/view/1312/1271

27. Minayo MCS. Sampling and saturation in qualitative research: consensuses and controversies. Rev Pesqui Qual [Internet]. 2017 [cited 2019 Sep 10];5(7):1-12. Available from: https://editora.sepq.org.br/index.php/rpq/article/view/82/59

28. Guerrero-Castañeda R, Menezes T, Ojeda-Vargas M. Characteristics of the phenomenological interview in nursing research. Rev Gaúcha Enferm. 2017;38(2):e67458. doi: 10.1590/1983-1447.2017.02.67458

29. Noreña AL, Alcaraz-Moreno N, Rojas JG, Rebolledo-Malpica D. [Applicability of the Criteria of Rigor and Ethics in Qualitative Research]. Aquichán. [Internet]. 2012 [cited 2019 Oct 10];12(3):263-74. Available from: https://aquichan.unisabana.edu.co/index.php/aquichan/article/ view/1824/2936 Spanish

30. Fuster DE. Qualitative research: hermeneutical phenomenological method. Propósitos Represent. 2019;7(1):201-29. doi: 10.20511/pyr2019. v7n1.267

31. Rodríguez I. [Physical activity and population aging. repercussion in the quality life]. Rev Colomb Enferm. 2013;9(9):12-20. doi: 10.18270/ rce.v9i9.560 Spanish

32. Loredo-Figueroa MT, Gallegos-Torres RM, Xeque-Morales AS, Palomé-Vega G, Juárez-Lira A. Level of dependency, self-care, and quality of life in the Elder adult. Enferm Univ. 2016;13(3):159-65. doi: 10.1016/j.reu.2016.05.002

33. Troncoso Pantoja C, Soto-López N. Family funcionality, autonomy and psychosocial welfare in the elderly. Horiz Méd. 2018;18(1):23-8. doi: 10.24265/horizmed.2018.v18n1.04

34. Torres WI, Flores MM. Predictive factors of subject well-being in older people. Rev Psicol. 2018;36(1):9-48. doi: 10.18800/psico.201801.001

35. Otway LJ, Carnelley KB. Exploring the associations between adult attachment security and self-actualization and self-transcendence. Self Identity. 2013;12(2):217-30. doi: 10.1080/15298868.2012.667570

36. Vargas-Santillán ML, Arana-Gómez B, García-Hernández ML, Ruelas-González MG, Melguizo-Herrera E, Ruiz-Martínez AO. Meaning of health: the experience of the elderly. Aquichan. 2017;17(2):171-82. doi: 10.5294/aqui.2017.17.2.6

37. Rodríguez CA, Collazo RM, Álvarez Vázquez L, Calero JR, Castañeda I, Gálvez González AM. Health care needs perceived by the Cuban older adults. Rev Cuba Salud Pública [Internet]. 2015 [cited 2020 Feb 13];41(3):401-12. Available from: https://www.scielosp.org/pdf/rcsp/2015. v41n3/401-412/es

38. Guerrero-Castañeda RF, Prado MLD, Menezes TMO, Galindo-Soto JA, Ojeda-Vargas MG. Life experiences that favor the plenitude and transcendence of the elderly being: a phenomenological-hermeneutical study. Rev Esc Enferm USP. 2019;53:e03476. doi: 10.1590/ S1980-220X2018029303476.

39. Reis LA, Trad LAB. Family support to elderly with commitment of functionality: a family perspective. Psicol Teor Prat [Internet]. 2015[cited 2020 Jan 22];17(3):28-41. Available from: http://pepsic.bvsalud.org/pdf/ptp/v17n3/03.pdf

40. Alfonso L, Soto D, Santos NA. Quality of life and perceived social support in the elderly. Rev Ciencias Médicas [Internet]. 2016 [cited 2020 Feb 13];20(1). Available from: http://scielo.sld.cu/scielo.php?script=sci_arttext\&pid=S1561-31942016000100012\&lng=es

41. Salazar M, Castro MJ. Loneliness and intergenerational cohabitation: resignifying care concept in a person's life. Rev Reflexiones [Internet]. 2019 [cited 2020 Feb 2];98(2):79-93. Available from: https://revistas.ucr.ac.cr/index.php/reflexiones/article/view/34152/38054

42. Gutz L, Camargo BV. Spirituality among older elderly: a study of social representations. Rev Bras Geriatr Gerontol. 2013;16(4):793-804. doi: 10.1590/S1809-98232013000400013 
43. Soares ASF, Amorim MISPL. Quality of life and spirituality in institutionalized senior citizens. Rev Port Enferm Saúde Ment [Internet]. 2015 [cited 2019 Dec 01];(SPE2):45-51. Available from: http://www.scielo.mec.pt/pdf/rpesm/nspe2/nspe2a08.pdf

44. Braz IA, Zaia JE, Bittar CML. Percepção da qualidade de vida de idosas participantes e não participantes de um grupo de convivência da terceira idade de Catanduva (SP). Estud Interdiscip Envelhec[Internet]. 2014 [cited 2019 Dic 05];20(2):583-96. Available from: https://seer. ufrgs.br/RevEnvelhecer/article/view/48261/35459

45. Santos CCN, Silva HS, Gutierrez BAO. Long term care and the institucionalized older adult perceptions about old age, successful aging and quality of care. Rev Kairós Gerontol. 2017;20(3):151-78. doi: 10.23925/2176-901X.2017v20i3p151-78

46. Scortegagna HM, Pichler NA, Fáccio LF. The experience of spirituality among institutionalized elderly people. Rev Bras Geriatr Gerontol. 2018;21(3):293-300. doi: 10.1590/1981-22562018021.180011

47. Buchanan JA, Ebel D, Garcia S, VandeNest FJ, Omlie CC. Age differences in perceptions of gerotranscendence: an examination of cosmic dimension behaviors. J Relig Spiritual Aging. 2016;28(3):239-54. doi: 10.1080/15528030.2016.1150934

48. Esperandio MRG, Escudero FT, Fanini L, Macedo EPN. Envelhecimento e espiritualidade: o papel do coping espiritual/religioso em pessoas idosas hospitalizadas. Interacao Psicol. 2019;23(2):268-80. doi: 10.5380/psi.v23i02.65381

49. Harrad R, Consentino C, Keasley R, Sulla F. Spiritual care in nursing: an overview of the measures used to assess spiritual care provision and related factors amongst nurses. Acta Biomed. 2019;90(Suppl 4). doi: 10.23750\%2Fabm.v90i4-S.8300 